\title{
Entrepreneurship and growth: lessons from an intellectual journey
}

\author{
Philippe Aghion
}

Accepted: 16 January 2016/Published online: 6 December 2016

(C) The Author(s) 2016. This article is published with open access at Springerlink.com

\begin{abstract}
This lecture is the story of an intellectual journey, that of elaborating a new-Schumpeteriantheory of economic growth. A theory where (i) growth is generated by innovative entrepreneurs; (ii) entrepreneurial investments respond to incentives that are themselves shaped by economic policies and institutions; (iii) new innovations replace old technologies: in other words, growth involves creative destruction and therefore involves a permanent conflict between incumbents and new entrants. First, we motivate and then lay out the Schumpeterian paradigm and point to a set of empirical predictions which distinguish this paradigm from other growth models. Second, we raise four debates on which the Schumpeterian approach sheds new light: the middle income trap, secular stagnation, the recent rise in top income inequality, and firm dynamics. Third and last, we show how the paradigm can be used to think (or rethink) about growth policy design.
\end{abstract}

Keywords Entrepreneurship - Creative destruction · R\&D · Entry · Exit · Competition · Technology frontier . Firm dynamics

This article is based on the author's presentation at the Global Award for Entrepreneurship Research ceremony in Stockholm, Sweden, May 10, 2016.

P. Aghion $(\bowtie)$

College de France, College de France, 3 rue d'Ulm, 75005 Paris, France

e-mail: paghion@fas.harvard.edu

P. Aghion

London School of Economics, London, UK
JEL classification $\mathrm{O} 10 \cdot \mathrm{O} 11 \cdot \mathrm{O} 12 \cdot \mathrm{O} 30 \cdot \mathrm{O} 31 \cdot \mathrm{O} 33 \cdot$ $\mathrm{O} 40 \cdot \mathrm{O} 43 \cdot \mathrm{O} 47$

\section{Introduction}

This lecture is the story of an intellectual journey, which Peter Howitt and I initiated almost 30 years ago when we decided to elaborate a new theory, now known as the "Schumpeterian theory," of economic growth. It is a theory where (i) growth is generated by innovative entrepreneurs; (ii) entrepreneurial investments respond to incentives that are themselves shaped by economic policies and institutions; and (iii) new innovations replace old technologies: in other words, growth involves creative destruction and therefore involves a permanent conflict between incumbents and new entrants. In this essay, we try to explain why and how to start up with the ambition of transforming growth theory, but eventually it was us who ended up being transformed. In particular, it explains how we started as pure applied theorists and ended up doing theory differently, through a constant back and forth between theory and data and a permanent dialog with empiricists themselves working with firmlevel data.

It is this story of the double transformation of the object and the subject which I want to tell during this lecture.

The remaining part of my presentation will be organized as follows. First, I will ask the question: why a new theory of economic growth? What did we find unsatisfactory with the dominant theory at the time, both 
theoretically and empirically? Second, I will lay out the Schumpeterian paradigm; I will point to a set of empirical predictions which distinguish this paradigm from other growth models, and I will tell you the story of how we started to dialog and then collaborate with microeconometricians. Third, I will raise four growth enigmas or debates on which the Schumpeterian approach sheds new light: the middle income trap, secular stagnation, the recent rise in top income inequality, and firm dynamics. Fourth and last, I will show how the paradigm can be used to think (or rethink) about growth policy design.

\section{Why did we need a new theory of economic growth?}

During my student years, the dominant paradigm in growth economics was the neoclassical growth model, which would be taught first under the assumption of a constant savings rate (the Solow model) and then in the context of an economy where a representative consumer decides about consumption, savings, and investment by maximizing her intertemporal utility (the Ramsey-CassKoopmans model).

The Solow model is the true template in growth economics, like Modigliani-Miller is the benchmark in corporate finance. This is first due to its being a model of elegance and parsimoniousness: the whole dynamics of the economy is described in two equations. The second reason is that the model shows very clearly why there can be no long run growth without technical progress. The model was published in 1956 (I was born that same year) and was rewarded by the Nobel Prize in 1987.

I will not bother you here with the details of this model which economists all know too well. But in a nutshell, the model describes an economy where final output is produced using capital as input, and where therefore it is the accumulation of capital that generates output growth. This corresponds to the first equation of the model. Then, the question is where does capital accumulation come from? This in turn is answered with the second equation of the model: capital accumulation comes from savings (aggregate savings equal aggregate investment in equilibrium), and savings - in turn - are in the Solow model are a constant fraction of final output, i.e., of aggregate GDP.

You might think that everything should go well in such an economy: more capital stock financed by savings will produce more final output, which will translate into more savings (as savings are proportional to final output) and therefore in still more capital stock and so on.

The problem is that we run into decreasing returns when trying to increase output by increasing the capital stock: the higher the existing stock of capital (number of machines), the lower the marginal increase in output from increasing the stock of capital by one unit (i.e., from adding one more machine). Thus, the lower the increase in savings, the lower the induced increase in capital stock.

At some moment, the process of capital accumulation runs out of steam (it stops when capital depreciation catches up with marginal savings) at which point the economy stops growing. To generate sustained longterm economic growth, there must be continuous technical progress to increase the quality (productivity) of machines. But, Solow does not tell us where technical progress is coming from.

In addition, if the model predicts conditional convergence, it does not give us the tools to understand why some countries converge to the standards of living (per capita GDP) of developed countries whereas other countries do not converge, or why some countries with lower capital stocks grow less rapidly than do other countries with higher capital stocks, or why capital does not necessarily flow from rich to poor countries (the socalled Lucas Paradox).

More fundamentally, the model does not look at growth from the point of view of firms and entrepreneurs, in which economic environment or "business climate" (institutions, policies) is more likely to stimulate innovation and entrepreneurship?

These motivated us to elaborate a new paradigm.

\section{The Schumpeterian paradigm}

In the fall of 1987 with Peter Howitt, we elaborated a growth model revolving around three important ideas outlaid by the Austrian economist Joseph Schumpeter (Aghion and Howitt 1992).

First idea: long-run growth is primarily generated by innovations (this is the natural counterpart of Solow's conclusion that no long-run growth can be expected without sustained technological progress).

Second idea: innovations result from entrepreneurial investments ( $R \& D$, training, computer purchase, etc.) and entrepreneurs respond to the economic incentives 
(positive or negative) which result from economic policies and economic institutions. Thus typically, innovation-based growth will be discouraged in environments with poor property right protection or with hyperinflation as these will damage the profitability from innovation. In other words, innovation-based growth is a social process and we can talk about policies of growth and institutions of growth.

Third idea: creative destruction. New innovations replace old technologies, and Schumpeterian growth is a conflicting process between the old and the new: it tells the story of all these incumbent firms and interests which permanently try to prevent or delay the entry of new competitors in their sector. Hence, there is something called "the political economy of growth."

A distinct prediction of the Schumpeterian growth model is that firm or job turnover should be positively correlated with productivity growth. Another distinctive implication of the model is that innovation-led growth may be excessive under laissez-faire. Growth is excessive (resp. insufficient) under laissez-faire when the business-stealing effect associated with creative destruction dominates (resp. is dominated by) the intertemporal knowledge spillovers from current to future innovators.

\section{Growth meets IO and our dialog with empiricists}

After an initial period of excitement with this new paradigm, some empirical studies came out which tempered our enthusiasm.

In particular, Blundell et al. (1995, 1999)—using UK firm-level data-raised doubt on another prediction of our model: the prediction that more competition should be detrimental to growth by reducing monopoly rents from innovation and thus entrepreneurs' incentives to invest in innovation in the first place as shown in Fig. 1 (incidentally, this latter argument has been used by Bill Gates when facing anti-trust action). Instead, when performing a linear regression of firms' innovation intensity and/or productivity growth on the degree of product market competition in the firms' sectors, Blundell et al. and Nickell found a positive correlation between competition and innovation/growth, as shown in Fig. 2.

How, if at all, could we reconcile theory and evidence? Should we throw the model in the garbage bin and start again from scratch? Or should we simply ignore the empirical challenges and proceed as before?
We went for a third way, namely, to look more closely at the model and try to identify the assumption or assumptions which generate this counterfactual prediction of a negative relationship between competition and growth.

And, we finally identified the culprit: in our initial model, only currently inactive firms innovate, not the currently active firms (i.e., not the current technological leaders). Thus, an innovating firm in our model would move from zero profit (pre-innovation) to a positive profit (post-innovation). Then, it is no wonder why competition would discourage innovation: competition reduces the post-innovation profit which here is equal to the net profit from innovation.

However, in reality, one finds at least two types of firms in most sectors of the economy and these two types of firms do not react in the same way to increased competition. You first have what we call "frontier firms," i.e., firms that are close to the current technological frontier in their sector. These firms are currently active and they make substantial profits even before innovating this period. Second, you have what we call the "laggard firms," i.e., firms far below the current technological frontier. These firms make low profits and try to catch up with the current technology frontier.

To try and understand why these two types of firms react differently to competition, imagine for a moment that what you are looking at are not firms but students in a classroom. And among them, you have the top students and the bottom of the class. And, suppose that you are opening the class to an additional student who turns out to be a very good student. This is how I represent an increase in competition in this context. How will the students react to this new student joining the classroom? The answer (here I refer to important work by Caroline Hoxby who studied precisely this) is that letting the new student in will encourage the other top students to work harder in order to remain the best, whereas it will further discourage students at the bottom of the class, as those will find it even harder to catch up.

Quite strikingly, firms react like classroom students: faced with a higher degree of competition in their sector, firms that are close to the technology frontier will innovate more in order to escape competition, whereas firms that are far from the technological frontier and try to catch up will be discouraged by the higher degree of competition and as a result innovate less: these latter firms behave like in the basic Schumpeterian model (see Fig. 3). 
Fig. 1 Competition and growth: theoretical prediction

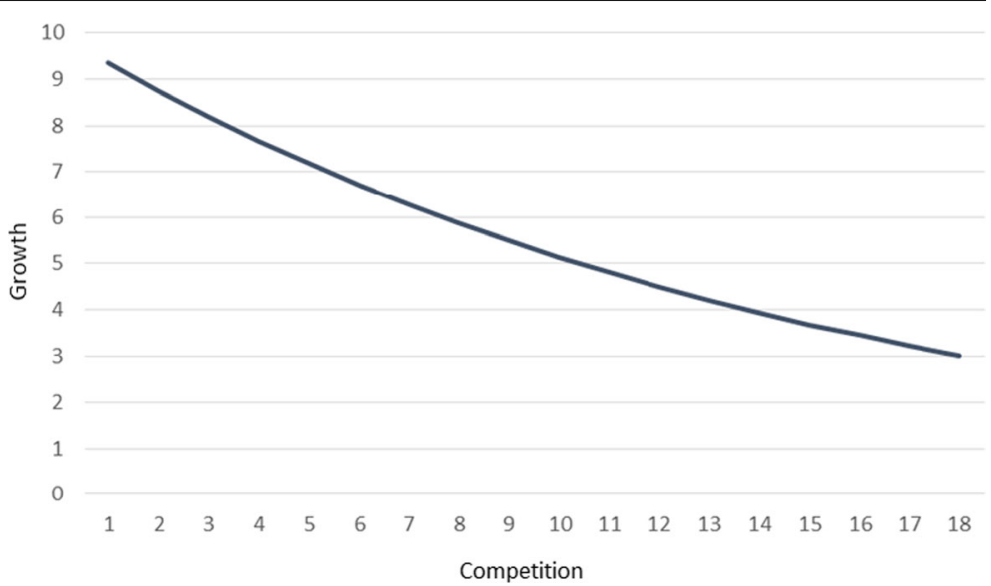

Overall, the effect of competition on innovation and productivity growth is an inverted $\mathrm{U}$, as shown in Fig. 4, which synthetizes the positive escape competition effect and the negative discouragement effect. The prediction of opposite reactions of frontier versus non-frontier firms to competition, and of an inverted U overall, was tested and confirmed in joint work with Richard Blundell, Nick Bloom, and Rachel Griffith using the same kind of firm-level data as in the empirical studies I mentioned above.

In the end, this exercise has been mutually enriching. On the one hand, our empirical colleagues realized that the relationship between competition and growth was more involved and subtle than what they thought based on their initial studies. On the other hand, we understood how to enrich our model so as to bring out not one but two basic effects of competition on innovation and growth, to identify conditions under which one or the other effect dominates and why when aggregating across all firms/sectors we obtain an inverted U relationship, as anticipated by Scherer (1967).

To reconcile theory with evidence, we extended our basic Schumpeterian model by allowing for step-by-step innovation in the Schumpeterian growth model (see Aghion et al. 1997, 2001). Namely, a firm that is currently behind the technological leader in the same sector or industry must catch up with the leader before becoming a leader itself. This step-by-step assumption implies that firms in some sectors will be neck-and-neck. In turn, in such sectors, increased product market competition, by making life more difficult for neck-and-neck firms, will encourage them to innovate in order to acquire a lead over their rival in the sector. This we refer to as the escape competition effect. On the other hand, in unleveled sectors where firms are not neck-and-neck, increased product market competition will tend to discourage innovation by laggard firms as it decreases the short-run extra profit from catching up with the leader.
Fig. 2 Competition and growth: empirical relationship

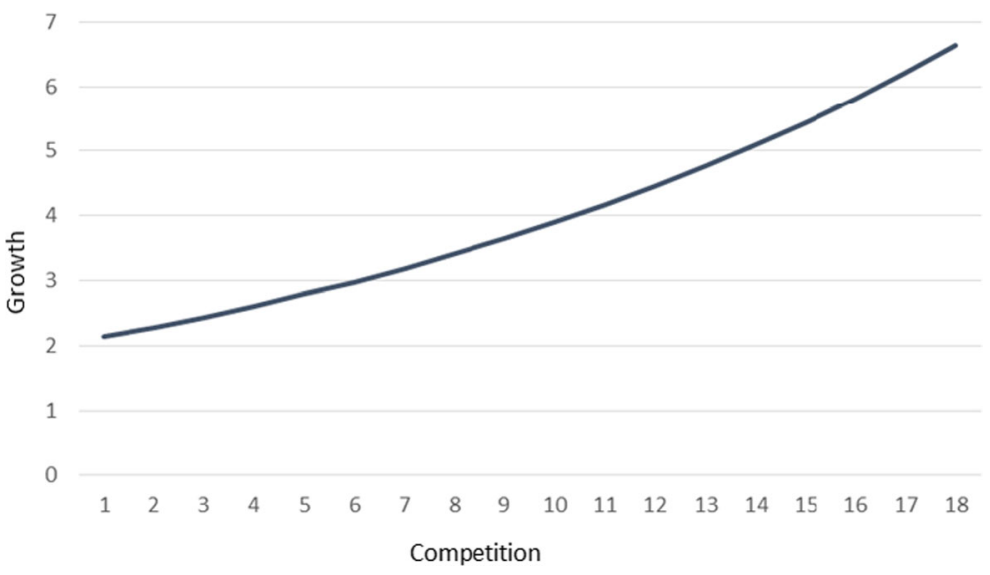


Fig. 3 Competition, growth, and distance to frontier

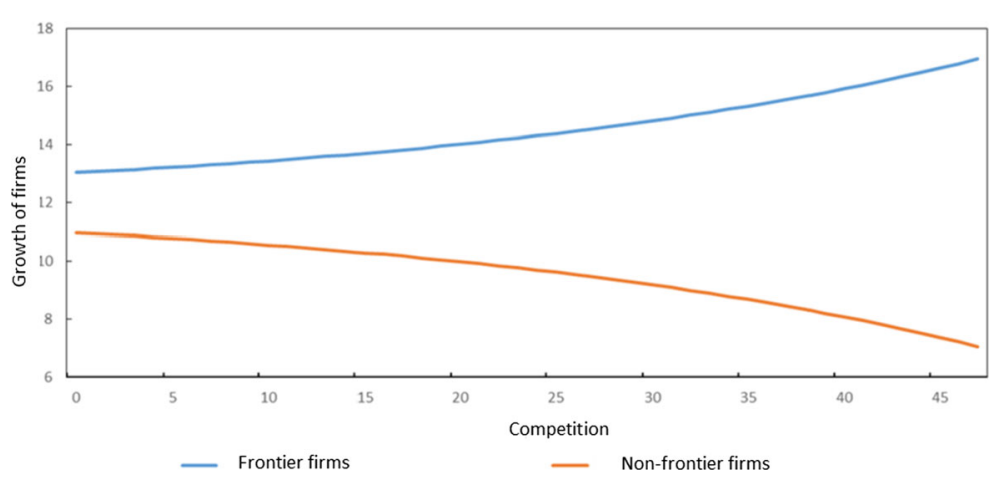

This we call the Schumpeterian effect. Finally, the steady-state fraction of neck-and-neck sectors will itself depend upon the innovation intensities in neck-andneck versus unleveled sectors. This we refer to as the composition effect.

This extended model predicts that in the aggregate, the relationship between competition and innovation should follow an inverted U pattern. Intuitively, when competition is low, innovation intensity is low in neck-and-neck sectors, therefore most sectors in the economy are neckand-neck (the composition effect); but precisely, it is in those sectors that the escape competition effect dominates. Thus, overall aggregate innovation increases with competition at low levels of competition. When competition is high, innovation intensity is high in neck-andneck sectors; therefore, most sectors in the economy are unleveled sectors, so that the Schumpeterian effect dominates overall. This inverted $\mathrm{U}$ prediction is confirmed by Aghion et al. (2005), using panel data on UK firms.

The prediction that more intense competition enhances innovation in "frontier" firms but may discourage it in "non-frontier" firms was tested by Aghion et al. (2009a) using again panel data of UK firms.

Another prediction from our extended model is that there is complementarity between patent protection and product market competition in fostering innovation. Intuitively, competition reduces the profit flow of noninnovating neck-and-neck firms, whereas patent protection is likely to enhance the profit flow of an innovating neck-and-neck firm. Both contribute to raising the net profit gain of an innovating neck-and-neck firm; in other words, both types of policies tend to enhance the escape competition effect.

That competition and patent protection should be complementary in enhancing growth rather than mutually exclusive is at odds with both, our first model and Romer (1990), where competition is always detrimental to innovation and growth (as we discussed above) for exactly the same reason that intellectual property rights (IPRs) in the form of patent protection are good for innovation: competition reduces post-innovation rents whereas patent protection increases these rents. But, it is also at odds with Boldrin and Levine (2008) who hold that patent protection is always detrimental to innovation and growth in their model where competition is good for growth.

Our prediction of a complementarity between competition and patent protection was tested by Aghion et al. (2013) using OECD country-industry panel data.
Fig. 4 Competition and growth: the inverted $U$ relationship

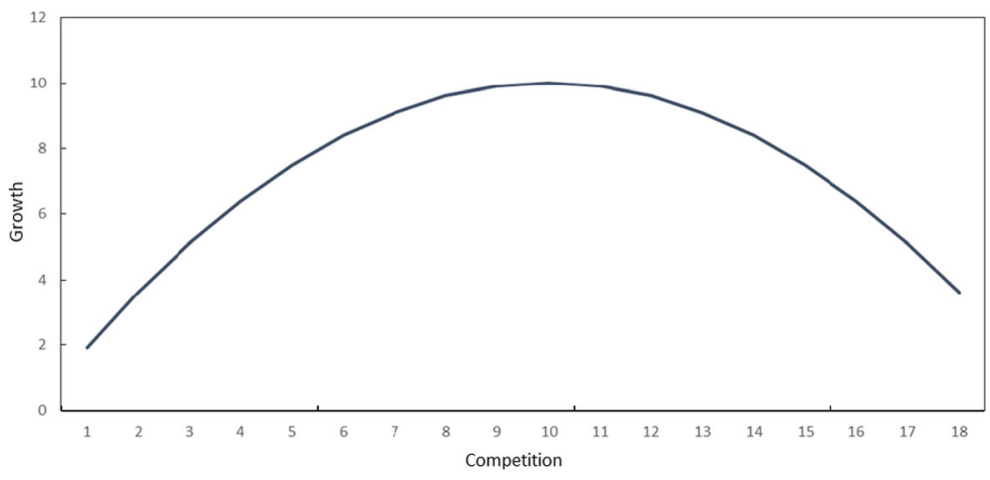




\section{Four growth enigmas}

This established dialog between Schumpeterian growth theory and firm-based empirical analysis has generated progress in approaching a number of growth enigmas. Here, I will limit myself to four growth enigmas: (i) the middle-income trap, (ii) secular stagnation, (iii) the dynamics of inequality, and (iv) firm dynamics. And, in each case, I will suggest policy implications.

\subsection{The middle income trap}

In 1890, Argentina enjoyed a GDP per capita approximately $40 \%$ that of the USA, which made it a middleincome country. This level was three times the GDP per capita of Brazil and Colombia and equivalent to that of Japan at the time. Argentina sustained this level of $40 \%$ of the GDP per capita of the USA through the 1930s. To be precise, Chow's test (a statistical test) shows a break around 1938 (Fig. 5), after which Argentina's productivity declines relative to American productivity by approximately $21 \%$ per year. What explains this drop-off?

Schumpeterian growth theory offers the following explanation. Countries like Argentina either had institutions or had implemented policies (in particular importsubstitution) that fostered growth by accumulation of capital and economic catch-up. They did not, however, adapt their institutions to enable them to become innovating economies. As demonstrated in joint work with Daron Acemoglu and Fabrizio Zilibotti, the greater the level of development in a country-i.e., the closer it gets to the technology frontier-the greater the role of cutting edge innovation as the motor of growth, replacing accumulation and technological catch-up (Acemoglu et al. 2006).

This phenomenon also exists in Asia. Japan, where the state has always tightly controlled competition, is another example: Japan's Ministry of Economy, Trade, and Industry (MITI) caps the number of import permits, and the state subsidizes investment by the big industrialfinancial consortia known a keiretsu. It is thus not surprising that from an extremely high level between 1945 and 1985 - the envy of other developed countriesJapan's growth has fallen to a very low level since 1985 .

In our previous discussion, we mentioned some recent evidence for the prediction that competition and free-entry should be more growth-enhancing in more frontier firms, which implies that they should be more growth-enhancing in more advanced countries since those have a larger proportion of frontier firms. Similarly, Acemoglu et al. (2006) show, using a cross-country panel of more than 100 countries over the 1960-2000 period, the following:

1. Average growth should decrease more rapidly as a country approaches the world frontier when openness is low.

2. High entry barriers become increasingly detrimental to growth as the country approaches the frontier.

These two empirical exercises point to the importance of interacting institutions or policies with technological variables in growth regressions: openness is particularly growth-enhancing in countries that are

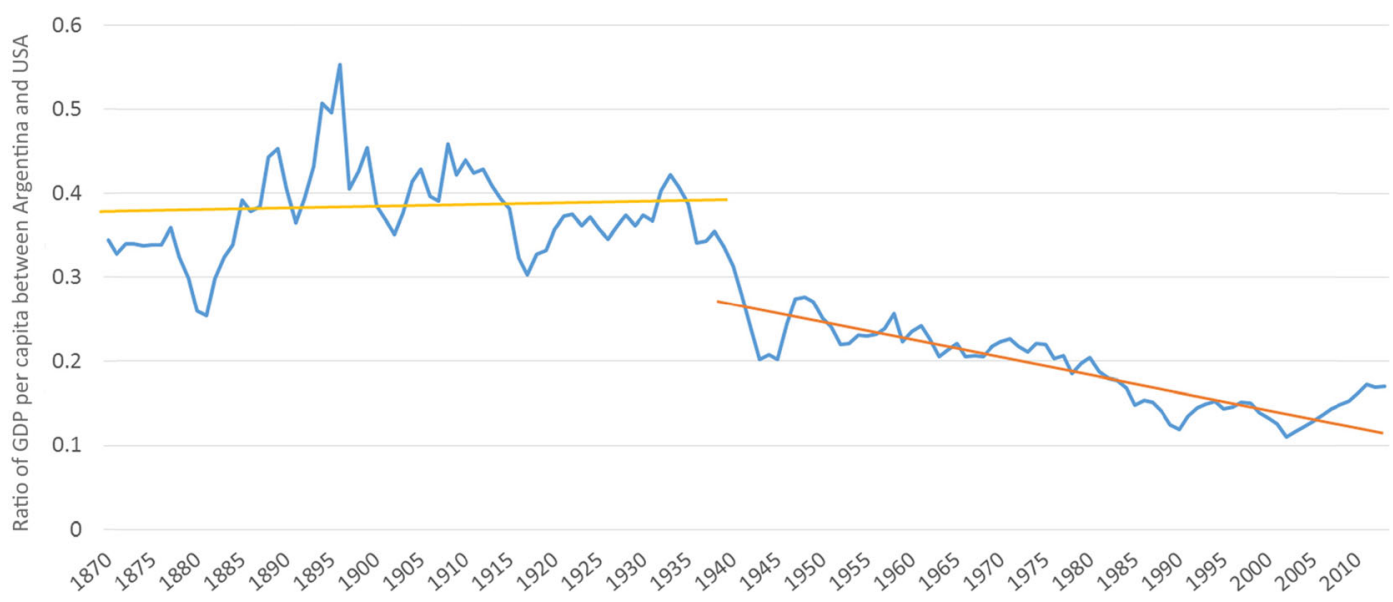

Fig. 5 Argentinian versus USA per capita GDP 
closer to the technological frontier; entry is more growth-enhancing in countries or sectors that are closer to the technological frontier.

Similarly, to the extent that frontier innovation makes greater use of research education than imitation, the prediction is that the more frontier an economy is, the more growth in this economy relies on research education. Aghion et al. (2009b) showed that research-type education is always more growth-enhancing in US states that are more frontier, whereas a bigger emphasis on 2-year colleges is more growth-enhancing in US states that are farther below the productivity frontier.

\subsection{The debate on "secular stagnation"}

In 1938, economist Alvin Hansen explained in his Presidential Address before the American Economic Association that in his opinion, the USA faced inexorable weak growth in the long term (Hansen 1939). The nation was just emerging from the Great Depression, and Hansen did not anticipate another World War that would stimulate a rebound in public spending and thereby of aggregate demand.

Since then, we have experienced another major financial crisis, the 2007 crisis, which led Larry Summers and others to revive the expression "secular stagnation" to characterize a situation that they assimilated to the one described by Hansen in 1938 (Summers 2013). Summers's argument is that investment demand was so weak that negative interest rates were necessary for a return to full employment.

Robert Gordon however believes that the risk of secular stagnation reflects a supply problem (Gordon 2012). Gordon proposes that the age of great innovations is past. He uses the metaphor of a fruit tree: the low-hanging fruit is the best; after that, the fruit is harder to pick and less juicy.

By way of example, the arrival of the Boeing 707 on the market in 1958 marked the end of progress in duration of air travel time. Until then, travel time had decreased exponentially; since then, not only has travel time ceased to decrease, it has actually increased due to the conjugated effects of energy saving and cost optimization.

Schumpeterian economists are more optimistic about the future than Summers and Gordon were. A first argument (Jorgenson) is that the revolution in information and communications technologies (ICT) has radically and durably improved IT-producing technology; meanwhile, globalization (which was concomitant with the ICT revolution) substantially increased the potential returns on innovation - the scale effect - as well as the potential downside of not innovating - the competition effect.

A second argument against the secular stagnation view is that we have witnessed an acceleration in innovation over the last several decades, which has been fully reflected by measured productivity growth.

In particular, Aghion et al. (2016) argue that innovation involving creative destruction is not properly taken into account by current measures of TFP growth. Whenever old products in the PPI are replaced by new products by new entrants, the statistical office often uses the price changes of surviving products to infer the price change of the replaced products.

Using the Schumpeterian growth paradigm to provide explicit expressions for missing growth from creative destruction, they estimate missing growth from creative destruction to lie between 0.4 and 0.8 percentage point on average per year.

The following figures help motivate this idea that creative destruction partly explains missing growth.

In Fig. 6, the number of patents correlates positively with productivity growth in American states where there is little creative destruction, but not in states experiencing creative destruction. Similarly, the correlation between the production of patents and productivity growth is more positive in America in sectors with little creative destruction (Fig. 7).

Finally, Fig. 8 depicts the relationship between the level of creative destruction in a sector at a particular time on the one hand and the correlation between TFP growth and the annual flow of patents on the other. More precisely, (i) each year over the period from 1994 to 2010, we rank 16 sectors, spanning the whole manufacturing industry, according to their level of creative destruction. Here, creative destruction is measured by half the sum of job creation and job destruction rates from the Quarterly Workforce Indicators series from the Census (see Davis et al. 1996); (ii) for any value $x$ on the horizontal axis, we group all the sector-years with level $x$ on the creative destruction scale, and compute the corresponding within-group average correlation $\mathrm{y}(x)$ between current yearly TFP growth and the current yearly number of patents.

Then, we see that the correlation between TFP growth and patenting over time is lower in sectors with higher rates of creative destruction. 
Fig. 6 Correlation between patenting and labor productivity growth

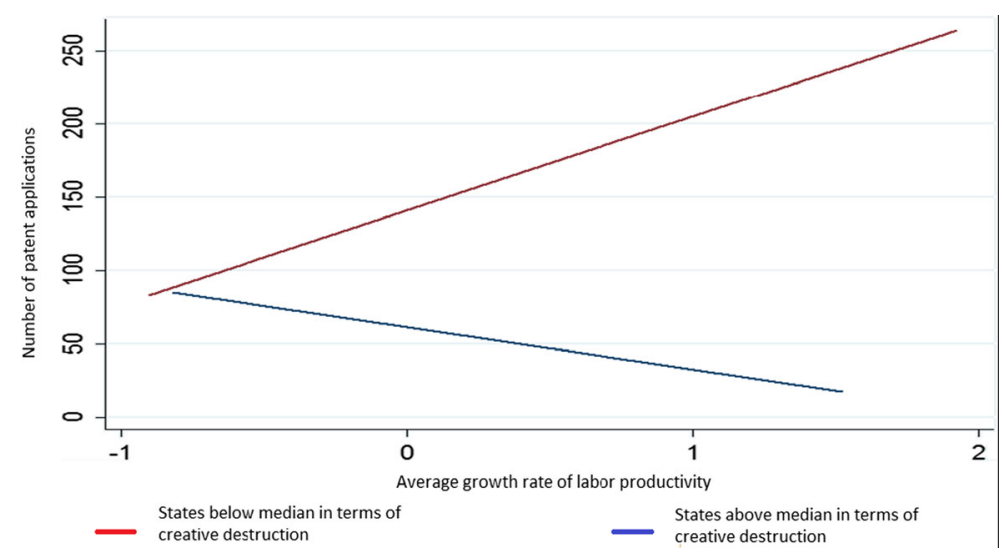

Third and last: my optimism regarding future growth prospects is also based on the observation that many countries have taken only belated and incomplete advantage of technological advances, e.g., because of structural rigidities or inappropriate economic policies. These countries did not adapt and therefore did not evolve from a catch-up economy to an innovation economy. The comparison between Sweden and Japan, as shown in the two graphs in Fig. 9a, b, is highly informative: growth of productivity accelerated in Sweden as it declined in Japan.

\subsection{Innovation, inequality, and social mobility}

Over recent decades, developed nations have experienced an accelerated increase in income inequality, especially at the top tier, with the top $1 \%$ capturing a rapidly growing share of total income (Atkinson et al. 2011; Piketty 2013). What explains this evolution?

Figure 10 compares the evolution of innovation in the USA since 1960 (as measured by the number of patents registered annually with the US Patent and Trademark Office), with extreme inequality (as measured by the share of income attributed to the top $1 \%$ of earners). The similarity in the two curves (innovation and the top $1 \%$ share of income) is striking.

A new study by Antonin Bergeaud, Richard Blundell, Ufuk Akcigit, David Hemous, and myself (Aghion et al. 2015) shows that this strong correlation reflects a causal link between innovation and extreme inequality: income from innovation contributes significantly to the increase in the share of income going to the top $1 \%$.

The observation that the observed increase in the top $1 \%$ results in part from innovation, and not solely from
Fig. 7 Correlation between patenting and labor productivity growth

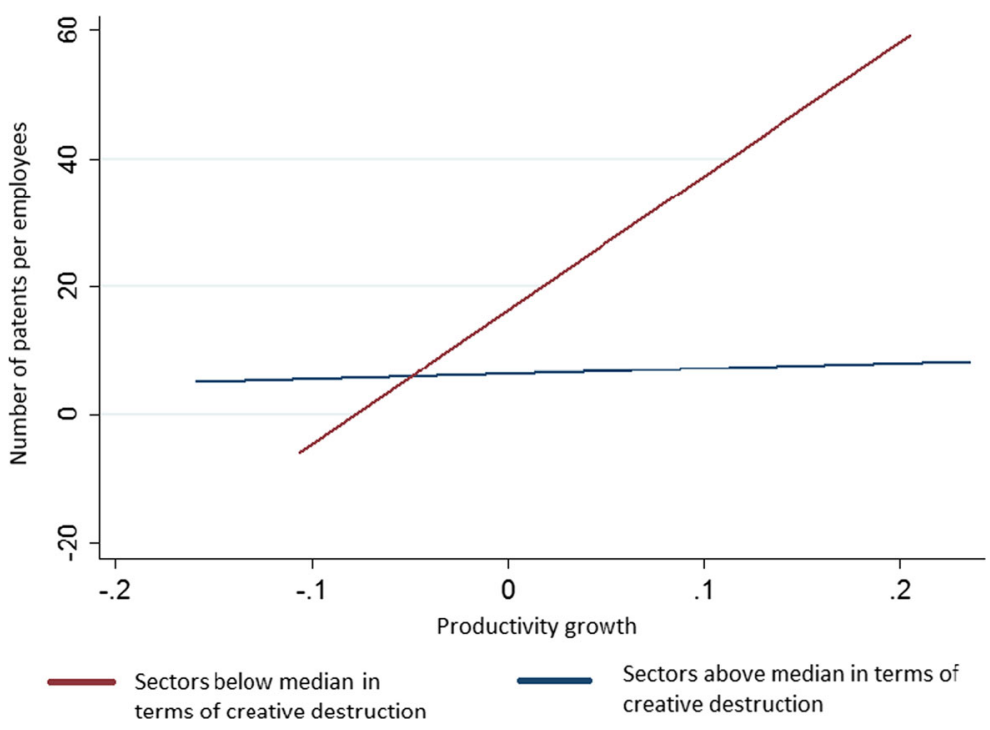


Fig. 8 Creative destruction and the correlation between TFP growth and patenting

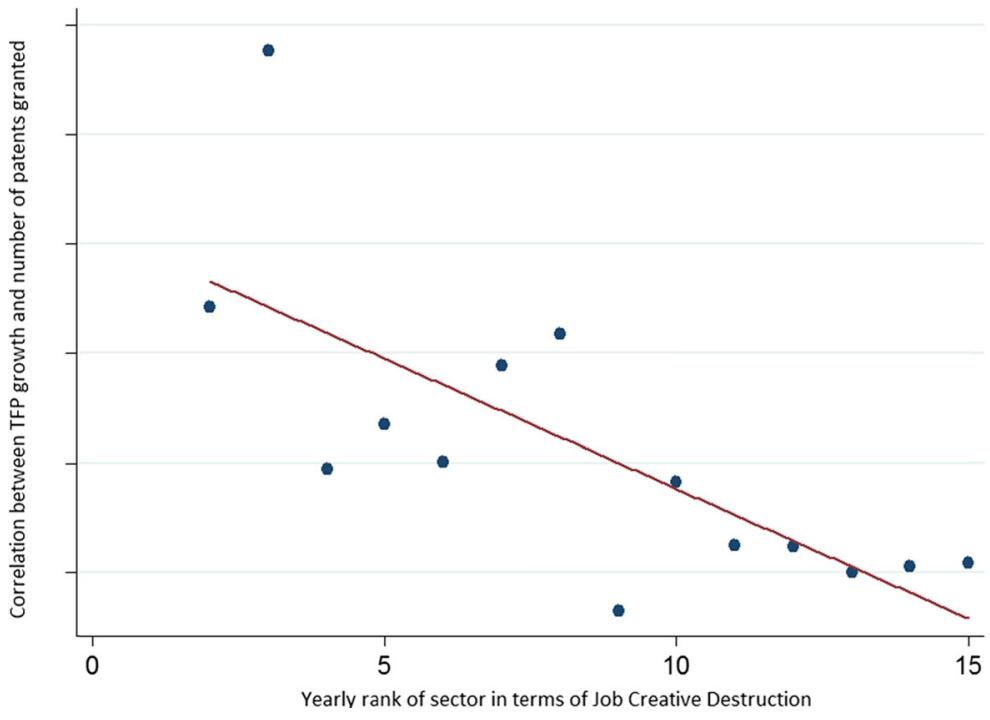

returns from real estate and speculation, provides an important insight, because innovation has virtues that the other sources of high income do not necessarily share.

First, as previously mentioned, innovation is the main motor of growth in developed economies. Second, although in the short term innovation benefits those who generated or enabled the innovation, in the long term, its
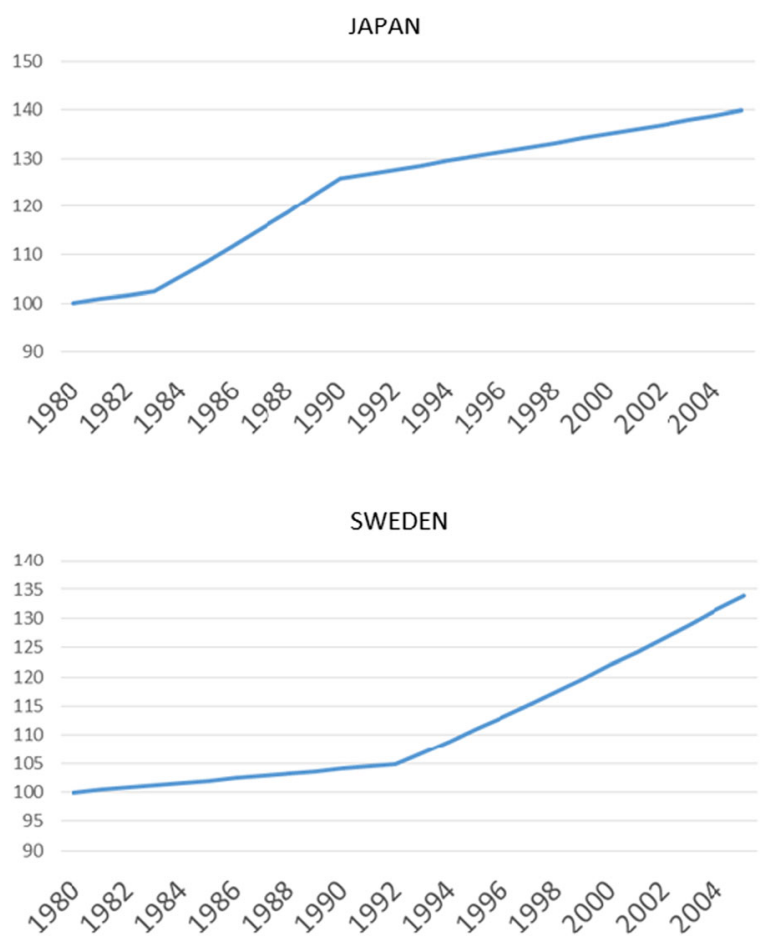

Fig. 9 Productivity growth: Sweden versus Japan returns are dissipated due to imitation and creative destruction. In other words, the inequality induced about by innovation is temporary. Third, because of the link between innovation and creative destruction, innovation generates social mobility: it enables new talent to enter the market and to displace (partially or totally) the firms in place. Thus, in the USA, California-currently the most innovating state of the union-far outpaces Alabama-which is among the least innovating statesboth in terms of the inequality of income going to the top $1 \%$ and in terms of social mobility.

The two figures are especially eloquent. The first figure (Fig. 11) describes the relationship between innovation and social mobility by comparing American municipalities. Social mobility is defined as the probability that an individual from a modest background (i.e., one whose parents were in the lowest quintile in the earnings scale between 1996 and 2000) will reach the highest quintile in 2010 upon reaching adulthood (based on the

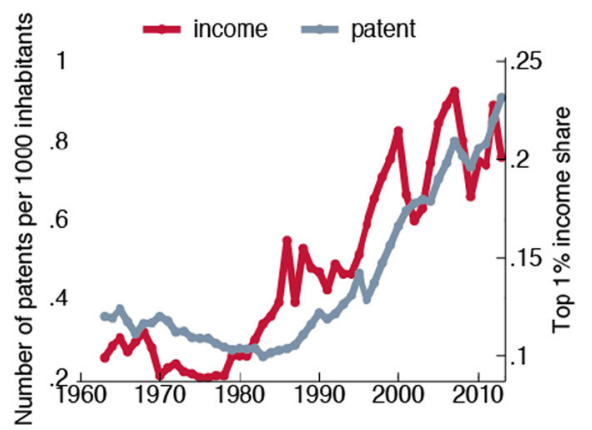

Fig. 10 The top $1 \%$ income share and the annual patent flow in the USA since 1960 
3.5

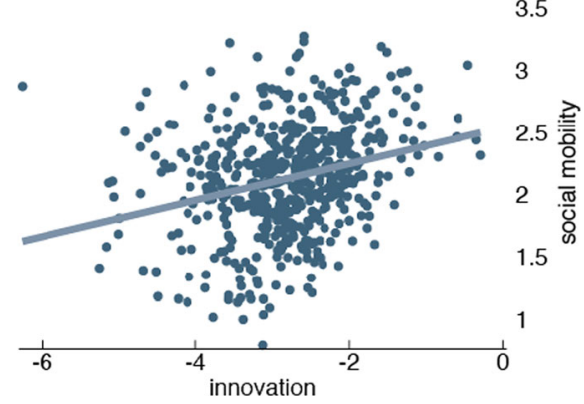

Fig. 11 Innovation and social mobility

work of Chetty et al. 2014). Innovation is measured by the number of patents filed with the US Patent and Trademark Office per resident in the municipality. The resulting graph shows a strong positive correlation between innovation and social mobility.

The second figure (Fig. 12) shows that there is no correlation between innovation and the broader measures of inequality such as the Gini coefficient, which measures the deviation between the actual distribution of income within an economy and a perfectly equal distribution.

By taking into account all of the pieces of the puzzle, we can respond to the question of whether we should object to innovation on the grounds that it contributes to income inequality. The response is no, because innovation generates growth. It does not increase inequality in broader terms, rather it stimulates social mobility. As a corollary to this discussion, tax policy must differentiate between innovation and other sources of top income. Put differently, we must distinguish between a Steve Jobs and a Carlos Slim. Tax policy that discourages innovation would not only inhibit growth but also reduce social mobility, whereas innovation does not increase inequality measured broadly.

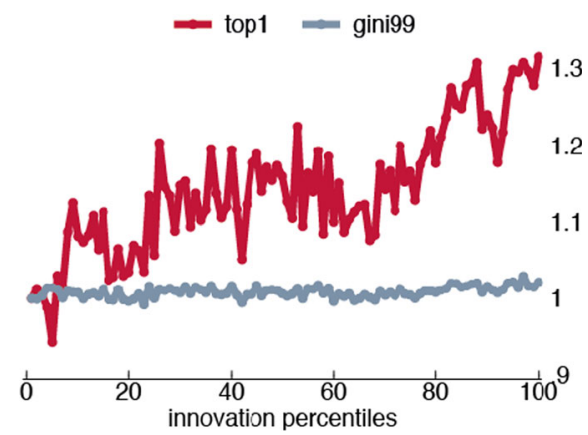

Fig. 12 Innovation percentiles and the top $1 \%$ and Gini99 inequality measures

\subsection{Firm dynamics}

Again, using both, theory and empirical analysis, younger generations of scholars have developed the Schumpeterian paradigm to look at the important question of the relationship between growth, innovation, and firm dynamics. Here, I should mention Daron Acemoglu, Ufuk Akcigit, Nick Bloom, Chang Tai Hsieh, William Kerr, Pete Klenow, Tor Jakob Klette, and Samuel Kortum as prominent figures in this new development.

The empirical literature on firm size distribution and on firm dynamics had pointed to a number of interesting stylized facts. In particular, (i) the firm size distribution is highly skewed, as shown in Fig. 13; (ii) firm size and firm age are highly correlated; and (iii) small firms exit more frequently, but the ones that survive tend to grow faster than do the average growth rate.

Incidentally, these are all facts that nonSchumpeterian growth models could not explain. Indeed, the first four facts required a new firm to enter, expand, and then shrink over time and eventually be replaced by new entrants: these and the last fact on the importance of reallocation are all associated with the Schumpeterian idea of creative destruction.

An important milestone to try and explain the above facts and more generally the relationship between growth, innovation, and firm dynamics was the Schumpeterian model by Klette and Kortum (2004). In this model, firms are defined as a collection of production units where successful innovations by incumbents will allow them to expand in product space (see Fig. 14).

Let us show why this paradigm allows us to explain the above stylized facts. Consider first the prediction that the size distribution of firms is highly skewed. Recall that in this model, firm size is summarized by the number of product lines of a firm. Hence, a firm needs to have succeeded many attempts to innovate in new lines and at the same survived many attempts by potential entrants and other incumbents at taking over its existing lines, in order to become a large firm. This in turn explains why there are so few very large firms in steady-state equilibrium, i.e., why firm size distribution is highly skewed as shown in a vast empirical literature.

Consider now the prediction that firm size and firm age are positively correlated. In the Klette-Kortum model, firms are born with a size of 1 . Subsequent successes are required for firms to grow in size, which naturally produces a positive correlation between size and age. 
Fig. 13 Firm size distribution with multiproduct firms

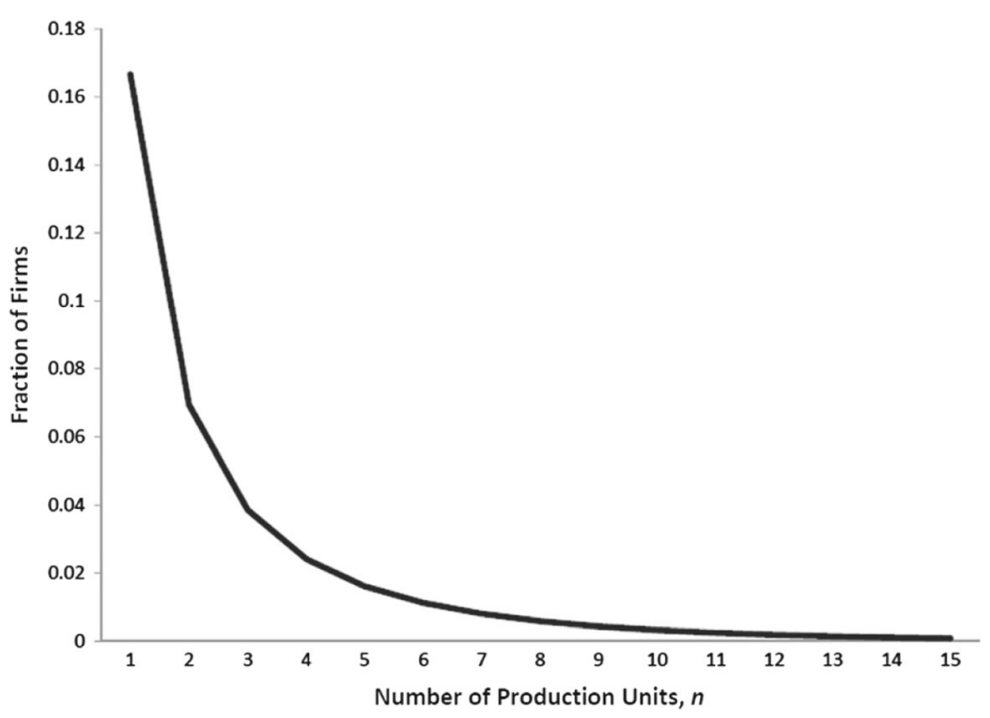

This regularity has been documented extensively in the literature.

Now coming to the prediction that small firms exit more frequently, and that the ones that survive tend to grow faster than average, in the Klette-Kortum model, it takes only one successful entry to make a one-product firm to exit, whereas it takes two successful innovations by potential entrants to make a two-product firm exit. The facts that small firms exit more frequently and grow faster conditional on survival have been widely documented in the literature.

\section{Rethinking growth policy}

Economists have responded in different ways to the question of whether to get involved in economic policy

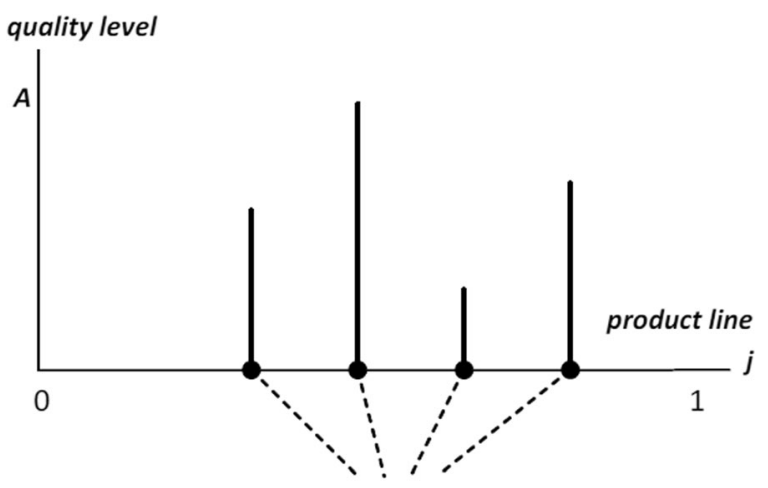

Firm $f$

Fig. 14 The firm as a collection of product lines debates or rather to stay out of the debates and concentrate on basic research. My work lies between these attitudes. Although I am first and foremost a researcher and a teacher, I find economic policy debates compelling for two reasons. First, as a strictly scientific matter, analyzing public policy and action enables us to better understand the mechanisms of growth. Second, theoretical and empirical economic analysis combats "false good ideas" by clarifying the terms of the policy debate.

\subsection{Learning from economic policy}

Public policy and active public intervention can be a tool for econometric analysis of growth models, as illustrated by the following two examples.

\subsubsection{Reforms as a tool: competition and innovation/ growth}

We looked earlier at the relationship between competition and innovation/growth. How can we be sure that this relationship is causal and not a mere coincidental correlation? The most commonly used method is that of instrumental variables: we utilize a variable that has a direct effect on competition and thereby on innovation but no direct effect on innovation. In our work with Richard Blundell and his team, we used the creation of the European Single Market (CEE) and the deregulation implemented by Margaret Thatcher as instrumental variables to establish the causal nature of the relationship 
between competition and innovation-induced growth in the UK.

\subsubsection{Cronyism as a tool: innovation-induced growth and higher education}

One of the policies that seem to foster growth in countries close to the technology frontier investment in higher education, especially at the $\mathrm{PhD}$ level. Working with Caroline Hoxby from Stanford University, we used political cronyism to instrument for research education.

In the USA, Appropriation Committees in the Senate and the House of Representatives have the power to allocate federal resources to the states to help finance their investments in infrastructure, schools, and universities and R\&D.

Aghion et al. (2009b) show the evolution of expenditures on higher education and research in three American states that are a priori at similar levels of development: Alabama, Mississippi, and Georgia. We see that the federal funds allocated to higher education and research for Alabama increased sharply when the senator from this state, Lister Hill, took office as the Chair of the Senate Appropriations Committee. This funding clearly stimulated innovation in the state.

This data provides us with a good tool to analyze the effect of expenditures in higher education and research on innovation and growth in the USA.

With a small dose of irony, we could argue that even if favoritism in politics is bad, it is a boon for econometricians on the lookout for variables to isolate the causal relationships that they seek to demonstrate. From this point of view, France's immoderate taste for experimentation in taxation makes my country a first-class laboratory for analyzing the effect of various tax policies on innovation and growth.

A more direct reason for a research economist to study public policy is that they may influence thinking on the subject. First, they can combat certain false truths and faulty reasoning (Joan Robinson responded to the question of why one should study economics, "to protect yourself from economists"). Second, they can help elucidate the terms of a very confused debate.

Two examples of false truths in growth policy are as follows:

1. More industrial policy is necessary to achieve competitiveness in an innovation economy.
2. Structural reform(s) and macroeconomic stimulus are mutually exclusive.

6.2 Rethinking industrial policy in an innovation economy

One of the pillars of the French Welfare State during the post-war economic boom was its industrial policy, which supported the large-state enterprises and subsidized investment in a small number of large private enterprises (the "national champions").

As we have seen, innovation-induced growth requires not only competition and low barriers to entry but also the discontinuation of activities that have become unprofitable. A Colbertist model of industrial policy that concentrates on a few national champions necessarily distorts competition and inhibits the entry of new, innovating firms.

This argument led some economists and decisionmakers to call for the flat-out abandoning of any industrial policy whatsoever, i.e., any sectorial targeting of public investment. They recommended rather that governments limit themselves to horizontal targets, such as schools, universities, research, or SMEs.

Between a nostalgic attachment to Colbertism and an absolute banishment of the slightest tendency in that direction, there is room for a new type of industrial policy, more favorable to competition and less biased in favor of a small number of existing firms. For example, recent research based on data from Chinese firms shows that an industrial policy that focuses on more competitive sectors (and not firms) and distributes subsidies in a transparent and egalitarian fashion within a sector, including new entrants, fosters growth and innovation (Aghion et al. 2012).

Put briefly, the approach to industrial policy should not be "yes or no" but rather to seek a new form of governance of industrial policy more compatible with innovation-induced growth. I hope this goal will inspire young generations of economists.

\subsection{Structural reforms and proactive macroeconomic policies}

Faced with a recession, some economists support stimulus policies (via public deficit and spending) and others argue for disengagement of the state, except to ensure well-functioning markets. 
Thus, to explain the resilience of the American economy compared to the European economy following the crisis of 2007-2009, some blame the lack of macroeconomic reactivity in Europe, while others point to the delay, by France and other European nations, to implement necessary structural reforms.

I believe that these two factors played a simultaneous and intertwined role: the persistent rigidities in the markets for goods and labor inhibited the impact of proactive macroeconomic policy. This opinion echoes the words of Mario Draghi, the Director of the European Central Bank (ECB), who declared at Bretton Woods in 2013 that he could only do half the work by relaxing monetary policy and that Member States would have to do the other half by making reforms.

Preliminary results from a joint research with Gabriel Chodorow and Emmanuel Farhi from Harvard University, and Enisse Kharroubi from the Bank for International Settlements, suggest that structural reforms and countercyclical monetary policy (lower interest rates during periods of recession and higher interest rates in periods of expansion) actually complement each other. In other words, by being more audacious with respect to structural reforms, not only do we incite our economic partners and the ECB to adopt more flexible macroeconomic policies but more importantly we also increase those reforms' positive impact on growth.

6.4 How to reconcile the goals of growth and reducing inequality

Researchers and policy-makers continually ask how we can make growth more inclusive and less inegalitarian. Many of my colleagues have attempted to analyze the correlation between income inequality broadly measured and the rate of growth of the GDP or the per capita GDP. These attempts, such as those of Abhijit Banerjee and Esther Duflo, have failed to show a clear relationship between inequality and growth. I would argue that a more promising approach is to (i) identify growth drivers in the economy being studied and (ii) analyze the effect of each of these drivers on phenomena such as the various measures of inequality: broad measures (such as the Gini coefficient), the share of income going to the top $1 \%$, and social mobility. As we have seen, innovation affects these measures in different ways.

In particular, my work with Gilbert Cette, Elie Cohen, and Jean Pisani-Ferry (Aghion et al. 2007) showed that the main growth drivers for a developed economy are education (especially higher education), competitive markets for goods and services, and a dynamic labor market. How do these drivers affect social mobility?

Education is "inclusive" in that it tends to increase social mobility and to reduce income inequality broadly measured. Indeed, Chetty et al. (2014) show that social mobility correlates positively with performance on education tests.

More surprisingly, the flexibility of the labor market and the market for goods seems to favor social mobility (see Aghion and Roulet 2015).

These results are encouraging: the growth levers for innovation also stimulate social mobility. In light of our earlier remarks, we can state with certainty that using an inappropriate tax policy to discourage innovation inhibits not only growth but also social mobility.

\section{What's next?}

It is always treacherous to attempt to predict the next major innovations and that is particularly true in the field of growth economics. Nonetheless, we can already perceive new fields of study emerging from the availability of new databases. I will suggest two areas for future research building on the Schumpeterian paradigm and methodology.

\subsection{Growth meets development}

Michael Kremer, Abhijit Banerjee, and Esther Duflo revolutionized development economics by introducing experimental random methods of analysis drawn from pharmaceutical science to evaluate the effectiveness of new medicines and vaccines (Banerjee and Duflo 2012). Their work enabled us to understand better the behavior of individuals and households in extreme poverty and to see how they react to different policies of aid and assistance.

But, firms play little role in these analyses and link between micro and macro development is not spelled out. However, one cannot disregard macroeconomic and systemic factors, nor the effects of resource reallocation, when the goal is to eradicate poverty at a national or regional level.

To see why macroeconomics matters, for example, the rate of poverty in urban zones of India (fraction of the population living on less than $\$ 1$ per day) fell from 

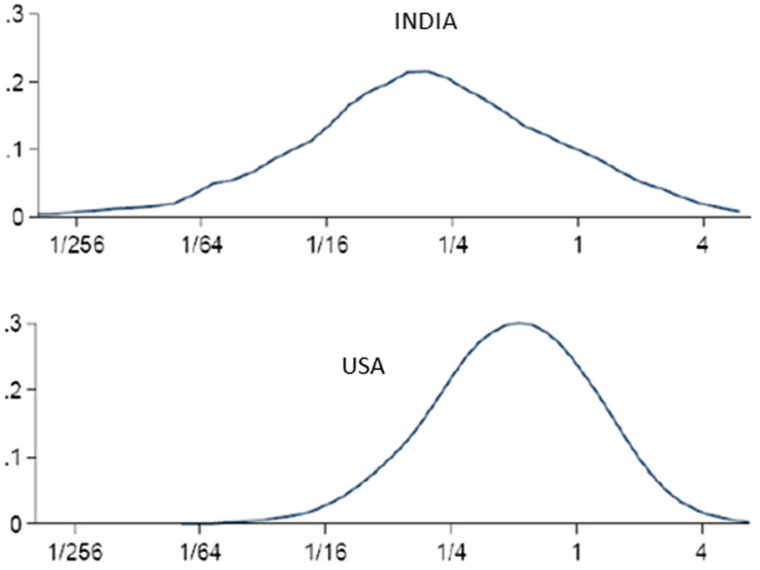

Fig. 15 Distribution of firms' productivity

$39 \%$ in $1987-88$ to $12 \%$ in $1999-2000$. Over the same period, growth took off: from less than $0.8 \%$ in the mid$1980 \mathrm{~s}$, it climbed to $3.2 \%$ in the $1990 \mathrm{~s}$. This upswing in growth in India resulted less from local actions than from systemic reforms such as the liberalization of trade and of the market for goods and services, with the suppression of the "Raj license" (Aghion et al. 2008).

But, looking at the systemic and macroeconomic aspects of a problem by no means implies we should ignore the microeconomic aspects, in particular at the level of the firm or sector. The two figures below, from the work of Pete Klenow and Chang-Tai Hsieh, illustrate this point (Klenow and Hsieh 2009). The first figure (Fig. 15) compares the distribution of Indian firms by productivity with the distribution of American firms. We observe that there are many more firms with low productivity in India than in the USA. The second figure
(Fig. 16) represents the evolution of the average size of a company as a function of its age, in India, Mexico, and the USA. It shows that American firms continue to grow whereas the growth of Indian firms drops off.

Both of these figures look at microeconomic characteristics. Yet, when placed side by side, they tell a story that has consequences on the Indian economy as a whole: the inability of Indian firms, even the most innovative and productive ones, to grow beyond a certain size, enables firms with low productivity to survive. But, in the aggregate, innovation and thereby the growth of the Indian economy overall, suffers.

To explain these two figures, we must consider the systemic characteristics of the Indian economy. As explained by Ufuk Akcigit, the limited growth of Indian firms over time appears to be tied to the fact that the majority of them remain family companies, which can be explained by the low average level of education and the resulting inadequate management skills, by defective infrastructure, and by the imperfections in the credit market in India (Akcigit et al. 2014).

A better understanding of the process of growth of firms and the reallocation of resources among firms or sectors would undoubtedly provide new keys to understand the relationship between growth and development and to find lasting remedies for underdevelopment and poverty in the world.

\subsection{Becoming an inventor}

New growth theories have shed light on the role of institutions and policies in favoring or preventing
Fig. 16 Link between the age and the size of firms

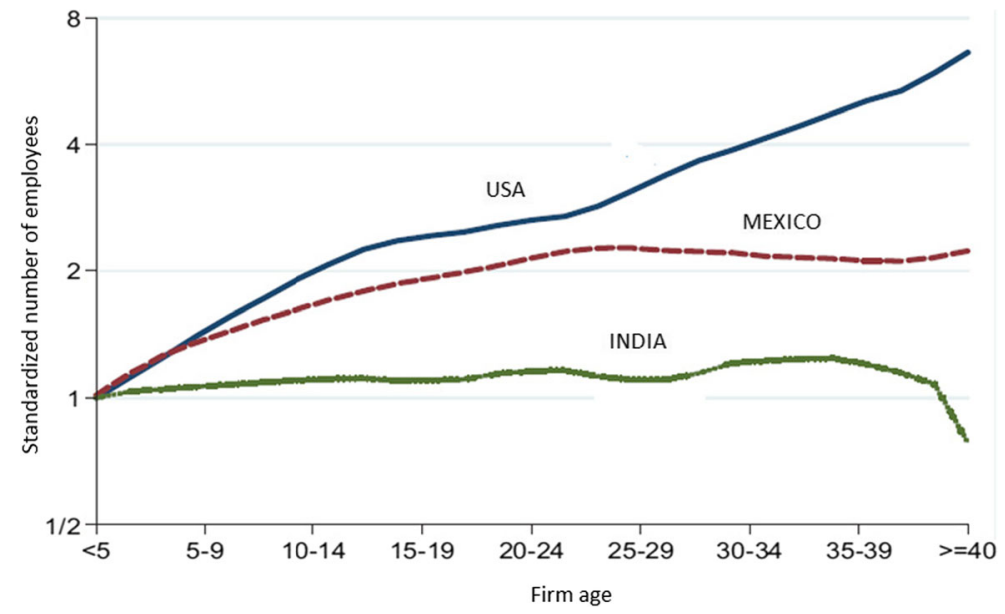


innovation-led growth. However, these models typically assume an economy with ex ante identical individuals who freely decide whether or not to become innovators and are indifferent in equilibrium between innovating and working in manufacturing. In practice, not everybody can become an innovator: whether one becomes an innovator or not is likely to depend upon the social environment (parental resources and education, the individual's own education, etc.) and upon innate ability, both of which are unevenly distributed across individuals. Moreover, individuals' social mobility is itself likely to be affected by whether or not the individual innovates and in a way which may also depend upon education, parental income education, and innate ability.

Understanding the extent to which society provides equal opportunities ex ante and at the end selects its most able citizens to become innovators, and getting a better sense of the income dynamics of innovators versus non-innovators is important for assessing whether innovation-led growth is "inclusive," i.e., does not exclude individuals based on social origin and instead promotes social mobility. Understanding these dynamics better should be helpful in designing institutions and policies that are more growth-enhancing precisely because they achieve a better selection of talents into innovation and provide better incentives to innovators.

\section{Conclusion}

Numerous paths are yet to be explored to better understand the enigmas of growth, the relationship between growth and innovation, and the role of institutions and economic policy in the process of development. Understanding this process will benefit not only science but society as a whole, because we are less fearful of what we understand.

Nearly 200 years ago, in 1835 in his book on Democracy in America, Alexis de Tocqueville wrote: "I cannot help fearing that men may reach a point where they look on every new theory as a danger, every innovation as a toilsome trouble, every social advance as a first step toward revolution, and that they may absolutely refuse to move at all for fear of being carried off their feet." My hope is that the work we have undertaken over the past 30 years and which I tried to summarize will contribute to dispel this apprehension.
Open Access This article is distributed under the terms of the Creative Commons Attribution 4.0 International License (http:// creativecommons.org/licenses/by/4.0/), which permits unrestricted use, distribution, and reproduction in any medium, provided you give appropriate credit to the original author(s) and the source, provide a link to the Creative Commons license, and indicate if changes were made.

\section{References}

Acemoglu, D., Aghion, P., \& Zilibotti, F. (2006). Distance to frontier, selection, and economic growth. Journal of the European Economic Association, 4(1), 37-74.

Aghion, P., \& Howitt, P. (1992). A model of growth through creative destruction. Econometrica, 60(2), 323-351.

Aghion, P., \& Roulet, A. (2015). Structural reforms and social mobility. Mimeo Collège de France.

Aghion, P., Harris, C., \& Vickers, J. (1997). Competition and growth with step-by-step innovation: an example. European Economic Review, Papers and Proceedings, 41(3-5), 771782.

Aghion, P., Harris, C., Howitt, P., \& Vickers, J. (2001). Competition, imitation and growth with step-by-step innovation. Review of Economic Studies, 68(3), 467-492.

Aghion, P., Bloom, N., Blundell, R., Griffith, R., \& Howitt, P. (2005). Competition and innovation: an inverted-U relationship. Quarterly Journal of Economics, 120(2), 701-728.

Aghion, P., Cette, G., Cohen, E., \& Pisani-Ferry, J. (2007). Les Leviers de la croissance française. Paris: La Documentation Française.

Aghion, P., Burgess, R., Redding, S., \& Zilibotti, F. (2008). The unequal effects of liberalization: evidence from dismantling the raj license in India. American Economic Review, 98(4), 1397-1412.

Aghion, P., Blundell, R., Griffith, R., Howitt, P., \& Prantl, S. (2009a). The effects of entry on incumbent innovation and productivity. Review of Economics and Statistics, 91(1), 2032.

Aghion, P., Boustan, L., Hoxby, C., \& Vandenbussche, J. (2009b). The causal impact of education on economic growth: Evidence from the U.S. Mimeo Harvard.

Aghion, P., Dewatripont, M., Du, L., Harrison, A., \& Legros, P. (2012). Industrial policy and competition. NBER Working Paper Series $n^{\circ} 18048$.

Aghion, P., Howitt, P., \& Prantl, S. (2013). Patent rights, product market reforms and innovation. NBER Working Paper Series $n^{\circ} 18854$.

Aghion, P., Akcigit, U., Bergeaud, A., Blundell, R., \& Hemous, D. (2015). Innovation and top income inequality. NBER Working Papers Series $n^{\circ} 21247$.

Aghion, P., Bergeaud, A., Boppart, T., Klenow, P., \& Li, H. (2016). Missing growth from creative destruction. Mimeo, London School of Economics.

Akcigit, U., Alp, H., \& Peters, M. (2014). Lack of selection and limits to delegation: firm dynamics in developing countries. Mimeo University of Pennsylvania. 
Atkinson, A., Piketty, T., \& Saez, E. (2011). Top incomes in the long-run history. Journal of Economic Literature, 49(1), 371.

Banerjee, A., \& Duflo, E. (2012). Repenser la Pauvreté. Paris: Seuil.

Blundell, R., Griffith, R., \& Van Reenen, J. (1995). Dynamic count data models of technological innovation. Economic Journal, 105(429), 333-344.

Blundell, R., Griffith, R., \& Van Reenen, J. (1999). Market share, market value and innovation in a panel of British manufacturing firms. Review of Economic Studies, 66(3), 529-554.

Boldrin, M., \& Levine, D. (2008). Against intellectual monopoly. Cambridge, MA: Cambridge University Press.

Chetty, R., Hendren, N., Kline, P., \& Saez, E. (2014). Where is the land of opportunity? The geography of intergenerational mobility in the United States. Quarterly Journal of Economics, 129(4), 1553-1623.

Davis, S., Haltiwanger, J., \& Schuh, S. (1996). Job creation and destruction. Cambridge, MA: MIT Press.
De Tocqueville, A. (1835) [1992]. De la Démocratie en Amérique. Paris: Gallimard, Bibliothèque de la Pleiade.

Gordon, R. (2012). Is U.S. Economic growth over? Faltering innovation confronts the six headwinds. NBER Working Papers Series $n^{\circ} 18315$.

Hansen, A. (1939). Economic progress and declining population growth. American Economic Review, 29(1), 1-15.

Klenow, P., \& Hsieh, C. (2009). Misallocation and manufacturing TFP in China and India. Quarterly Journal of Economics, 124(4), 1403-1448.

Klette, T., \& Kortum, S. (2004). Innovating firms and aggregate innovation. Journal of Political Economy, 112(5), 986-1018.

Piketty, T. (2013). Le Capital au XXe Siècle. Paris: Seuil.

Romer, P. (1990). Endogenous technical change. Journal of Political Economy, 98(5), 71-102.

Scherer, F. (1967). Market structure and the employment of scientists and engineers. American Economic Review, 57(3), 524 531.

Summers, L. (2013). Why stagnation might prove to be the new normal. Financial Times, December 15, 2013. 